\title{
ANALYSIS OF OUTSOURCING SYSTEM AND WORK MOTIVA- TION ON EMPLOYEE PERFORMANCE
}

\author{
Neng Eti Setiawati \\ Magister of Management, Postgraduate, Universitas Sultan Ageng Tirtayasa \\ E-mail address: nerathea@gmail.com
}

\begin{abstract}
Currently, many companies are implementing outsourcing systems for their company's HR management. Outsourcing is a company that uses human resources from other parties (external) to carry out work activities that are usually handled by internal staff and resources. The problem that exists is because the outsourcing system affects the performance of employees at a food ingredients factory in Cilegon, where there are still high complaints from clients regarding the decline in the performance of forklift operator employees placed in their company. This shows the inaccuracy at work leads to a lack of employee motivation. Employee motivation problems can be the cause of low employee performance in a company. The objectives of this study are (1) to determine the effect of the outsourcing system on employee performance and (2) to see the effect of work motivation on employee performance. This study tested 2 hypotheses with data sources originating from respondents of outsourcing employees of PT. AMP, a division of forklift operators at the Cilegon grocery factory, analyzed the influence of the outsourcing system and work motivation on employee performance in the company. The research limitations of this research are information, primary and secondary data in this study were only obtained from PT. AMP. The population and sample of this study were all outsourced employees of PT. The AMP division of forklift operators placed 30 people in a food ingredients factory in Cilegon. This study uses a quantitative approach method. The data collection technique used primary data in the form of a questionnaire. The data analysis technique of this research used the Structural Equation Modeling-Partial Least Square (SEM-PLS) method. Based on the results of the direct influence hypothesis research, it is known that the outsourcing system has a positive and significant effect on employee performance. And motivation has no significant effect on employee performance
\end{abstract}

\section{Keywords: Outsourcing System, Motivation and Employee Performance}

Received: 18 November 2021 ;

Accepted: 21 December 2021 ;

Publish: December 2021

How to Cite:

Setiawati, N.E. (2021). Analysis of Outsourcing System and Work Motivation on Employee Performance. Journal of Business and Behavioural Entrepreneurship, 5(2), 108117. https://doi.org/10.21009/JOBBE.005.2.13 


\section{INTRODUCTION}

Human resources are important assets in companies and organizations. To achieve competitive advantage, organizations urgently need human resources who have high levels of energy, productivity and commitment in their workplace (Bakker and Schaufeli, 2008; Chen, 2018), because someone with a positive attitude at work can have an impact on organizational success ( Al Mehrzi and Singh, 2016; Gruman and Saks, 2011). It is very important to know how human resource management practices impact on employees to show a high level of performance (Karatepe, 2013). According to Cropanzano and Mitchell (2005) and Saks (2006) when organizations get sufficient human resources, they are more likely to pay employees with better performance. This applies to permanent employees and employees from outside the company or called outsourcing. At this time many companies are implementing outsourcing systems for the management of their company's human resources. Outsourcing is a company using human resources from other parties (external) to carry out work activities which are usually handled by internal staff and resources.

The author conducted research at PT. AMP, this company is a company engaged in the field of man power supply (outsourcing). Outsourcing is a contract employee with a certain time work agreement (PKWT), so that outsourced employees feel they are not guaranteed job security. This is a problem for them regarding the continuity of work (Rachmawati Rachman, 2019). And there are still high complaints from clients regarding the decline in the performance of the forklift operator division employees who are placed in the company. This shows the inaccuracy at work which leads to a lack of employee motivation. According to Abraham Maslow, the need for security is one of the hierarchy of needs after the most basic needs for employees, namely physiological needs (Emron, et.al, 2020:175).

The need includes a sense of security at work and old age guarantees in this case there are three possibilities, the continuation of the work contract, becoming a permanent employee or terminating the work contract. Employee motivation problems can be the cause of low employee performance in a company. Work motivation can be interpreted as the strength possessed by an individual that can increase his potential in carrying out an activity (Prabowo, et al, 2017) in Muhammad Tafrizi Priarso et al, 2018. Motivation refers to the direction, intensity, and persistence of effort. Employee motivation is the key to the organization, where the organization spends a lot of effort trying to maximize employee motivation and maximize employee expertise which triggers increased employee performance which in turn will achieve organizational performance (Michael Howe and Russell E. Johnson, 2016). The author hopes that employees and companies can benefit from this research regarding outsourcing systems and work motivation in order to improve employee performance for the better so that organizational performance is achieved.

\section{LITERATURE REVIEW}

\section{Performance}

Performance is the result that comes from a process that refers to and can be measured on the terms and accuracy of a certain period in accordance with what has been previously determined (Emron, et.al, 2020:188).

The dimensions that become benchmarks in achieving or measuring performance according to John Miner in (Emron, at.al, 2020: 192) are as follows: (1) quality, 
namely the level of error, damage, accuracy, (2) quantity, namely the amount of work generated, (3) the use of time at work, namely the rate of absenteeism, tardiness, effective working time/lost working hours and (4) collaborating with other employees at work.

\section{Outsourcing System}

Outsourcing is that part of the work is handed over to other companies by entering into a contracting agreement (provider) of work services (Khairani, 2016, in Maryam Dunggio, 2019:168). In labor law, outsourcing can be found implicitly in Law no. 13 of 2003 concerning Manpower. There are articles on outsourcing arrangements, which can be found in Article 64, Article 65, and Article 66. Article 64 reads: A company may hand over a part of the execution of work to another company through a work charter agreement or the provision of worker or labor services made in writing. It is further clarified in the provisions of Articles 65 and 66 which regulates the agreement which can be in the form of (a contract for contracting work and providing worker or labor services) based on PKWT and PKWTT contracts and the parties involved are the relevant business actors, namely; (outsourced workers or workers, companies providing or accepting jobs and companies using outsourcing or users).

In the outsourcing work system according to (Khairani, 2016) in Maryam Dunggio, 2020:168 mentions that there are several indicators. These include (1) employment contracts, (2) remuneration systems, (3) duration of work, (4) termination of employment and (5) worker welfare.

\section{Work Motivation}

Motivation can be seen in terms of how individuals choose to use their limited personal resources (such as time and energy) towards the achievement of certain results, it is the extent to which a person is driven to achieve something. Motivation refers to the direction, intensity, and persistence of effort. Employee motivation is the key to the organization, and organizations spend a lot of effort trying to maximize employee motivation to maximize employee expertise and in turn organizational performance is achieved (Michael Howe and Russell E. Johnson, 2016).

There are five levels of needs arranged in a hierarchy according to Abraham Maslow's motivational theory, including (1) physiological needs, (2) safety needs or security needs, (3) affection needs or love needs (needs for safety). to be liked), (4) esteem needs (needs for recognition), and (5) self-actualization needs (needs for selfdevelopment). 


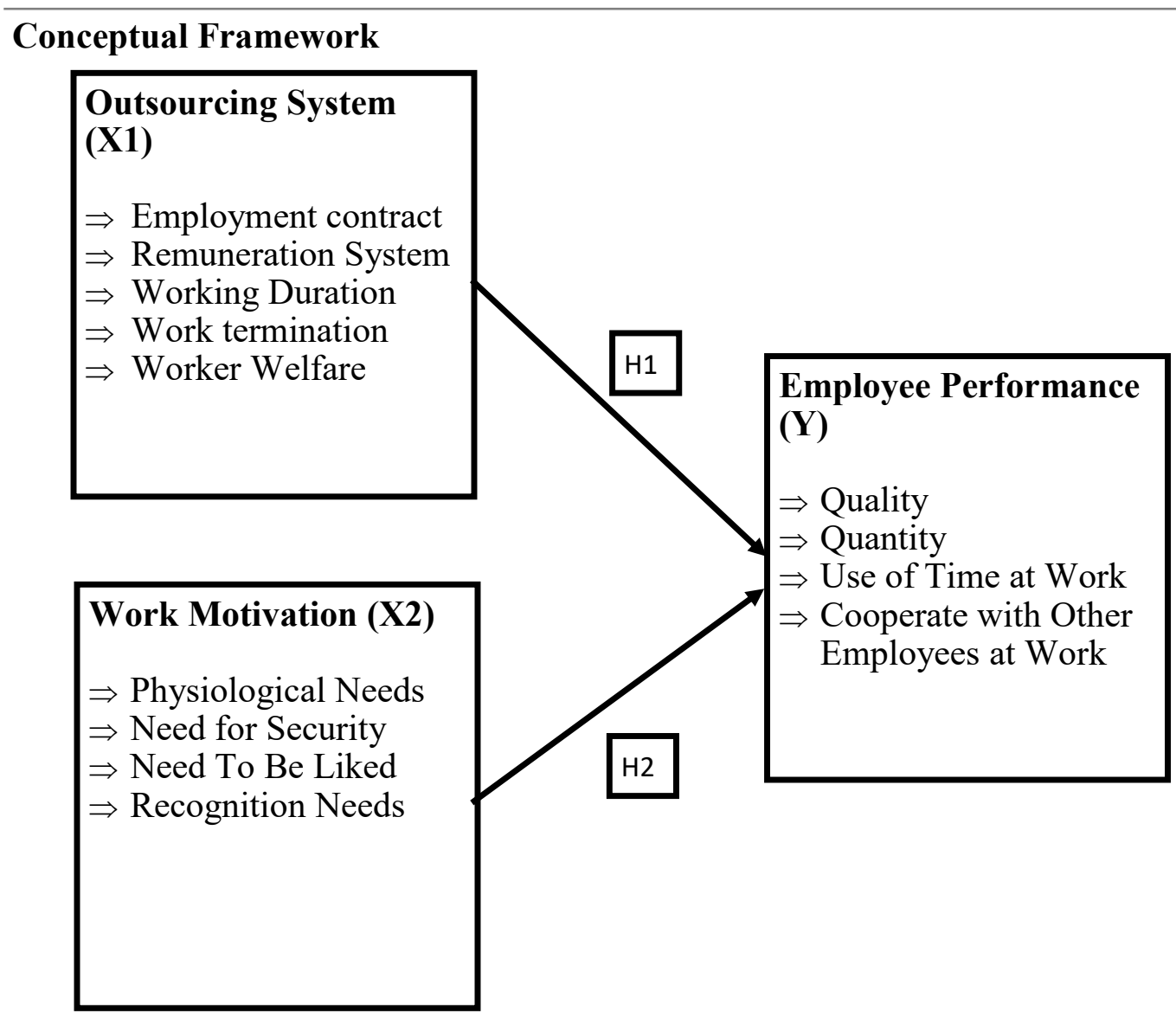

Figure 1. Conceptual Framework

Source: Processed in research, 2021

\section{Hypothesis Development}

By looking at the theoretical review and framework of thinking above, the hypotheses in this study can be stated as follows:

The results of previous research from (Maryam Dunggio and Rosario, 2020) state that there is a positive and significant influence between the outsourcing system on employee performance, this shows that the better the implementation of the provisions contained in the outsourcing system, the higher the employee performance.

H1: The outsourcing system has a positive and significant effect on employee performance

The results of research from (Ketut IR Sudiardhita, et.al, 2018) state that there is a positive and significant influence between motivation on employee performance. This shows that if work motivation increases, the performance of employees will also increase.

$\mathrm{H} 2$ : Work motivation has a positive and significant effect on employee performance 


\section{RESEARCH METHODOLOGY}

This study uses quantitative methods. Quantitative research methods are methods in which the data is presented in the form of numbers and analysis uses statistics (Sugiyono, 2019:7).

The population of this research are all outsourcing employees of PT. The AMP division of forklift operators placing 30 people in a food ingredients factory in Cilegon. The sample of this research is 30 outsourcing employees of PT. AMP's forklift operator division is placed in a food ingredients factory in Cilegon. To determine this sample, the researcher used the saturated sampling method. This method is a sampling technique if all members of the population are used as samples. This can be done if the population is relatively small (Sugiyono, 2019:85).

The data collection technique of this research was using a questionnaire (questionnaire). This technique is a technique that is carried out by providing structured questions or statements to respondents (Sugiyono, 2019:142). The questionnaire in this study contains statements for respondents to choose one answer with alternative answers consisting of intervals worth 1-10. The measurement scale used for the assessment of the questionnaire using a Likert scale. Starting from a scale of 1 for the rating level of "Strongly Disagree", to a scale of 10 "strongly agree".

The data analysis technique of this research uses the Structural Equation Modeling-Partial Least Square (SEM-PLS) method. According to Ghozali in (Ketut IR Sudiardhita, et.al, 2018), SEM-PLS is a multivariate analysis technique that allows researchers to be able to examine the relationship between complexes (recursive and non -recursive) in order to get a comprehensive picture of the overall model. This complex relationship can be constructed from one or more dependent variables with one or more independent variables. Each variable can be a construct that is built from several indicators.

\section{RESULTS AND DISCUSSIONS}

\section{Analysis of the Measurement Model (Outer Model)}

The measurement model is described as a model between latent variables (constructs) with related indicators. The indicators for each variable can be referenced from references (Azuar Juliandi, 2018).

\section{Construct validity test}

The results of the first data processing, on the outsourced system variable there is an invalid indicator $(<0.60)$ on the $\mathrm{SO} 5$ indicator $=0.503$. so the indicator with a loading factor value of less than 0.60 is removed. In order to meet the requirements of convergent validity above 0.60 , where the Rule of thumb for the loading factor value is $>0.60$ (Ghozali \& Latan, 2015). After processing the second data, it turns out that there is still a loading factor value below 0.60 , namely the $\mathrm{SO} 4=0.595$ indicator, so that the indicator is deleted and the third data processing is carried out. In the third data processing, all indicators have a loading factor value above 0.60 , so that all indicators of each variable have met the convergent validity requirements.

\section{Convergent Validity}

In the convergent validity test there are two value criteria generated, namely: the 
loading factor value and the average variance inflation factor (AVE) value. The results of these two research values can be seen in table 1 and table 2, as follows:

Table 1.

Outer Loading Value of Each Research Variable Indicator

\begin{tabular}{|llc|}
\hline Indicator & \multicolumn{1}{c|}{ Variable } & Outer Loading \\
\hline SO1 & Outsourcing System & 0.822 \\
SO2 & Outsourcing System & 0.896 \\
SO3 & Outsourcing System & 0.792 \\
\hline MO1 & Motivation & 0.730 \\
MO2 & Motivation & 0.867 \\
MO3 & Motivation & 0.828 \\
MO4 & Motivation & 0.769 \\
\hline KP1 & Employee Performance & 0.828 \\
KP2 & Employee Performance & 0.833 \\
KP3 & Employee Performance & 0.830 \\
KP4 & Employee Performance & 0.749 \\
\hline
\end{tabular}

\section{Source: Output of Research Data Analysis Results, 2021}

Based on the output of the loading factor value of the outsourcing system variable, after removing two indicators, namely SO4 and SO5, so that the remaining three measurement indicators, four indicators of motivation variable measurement, and four indicators of employee performance measurement as a whole already have a loading factor value above 0.60 . Thus, all indicators forming the outsourcing system construct, motivation, and employee performance are declared valid.

\section{AVE Test}

The rule of thumb for the average variance inflation factor (AVE) parameter is $>$ 0.50 (Ghozali \& Latan, 2015). The AVE value can be seen in table 2

Table 2.

Average Variance Inflation Factor (AVE) value

\begin{tabular}{ll} 
Variabel & AVE \\
\hline Outsourcing System & 0.702 \\
Motivation & 0.641 \\
Employee Performance & 0.658 \\
\hline
\end{tabular}

Source: Output of Research Data Analysis Results, 2021

The AVE value of all constructs has met the requirements of the value $>0.50$, so that based on the AVE value test on the outsourcing system variable, employee motivation and performance are declared valid. 


\section{Determinant validity}

The value of the rule of thumb parameter cross loading for the measurement of the validity of the determinants is $>0.70$ for each variable (Ghozali \& Latan, 2015). The results are shown in table 3 .

Table 3.

Cross Loading Indicator Value

\begin{tabular}{cccc}
\hline & Employee Performance & Motivation & Outsourcing System \\
\hline Empoxee Performance & 0.811 & & \\
Motivation & 0.398 & 0.801 & \\
Outsourcing System & 0.715 & 0.349 & 0.838 \\
\hline
\end{tabular}

Source: Output of Research Data Analysis Results, 2021

From table 3, it can be seen that the cross loading value of each indicator on the construct is greater. So it can be concluded that the latent variable (construct) has good discriminant validity, which can be seen in the value of the construct indicator which is greater than the other block indicators.

\section{Reliability Test}

To find out the proof of accuracy, consistency and accuracy of the instrument in measuring the construct, namely by conducting a reliability test. In SEM PLS, it can be done with Cronbach's alpha and composite reliability for construct measurement with reflexive indicators. The rule of thumb for this parameter is $>0.70$ (Ghozali\&Latan, 2015).

Tabel 4

Cronbach's Alpha dan Composite Reliability Value

\begin{tabular}{lcc}
\hline & Cronbach's Alpha & Composite Reliability \\
\hline Employee Performance & 0.832 & 0.885 \\
Motivation & 0.821 & 0.877 \\
Outsourcing System & 0.788 & 0.876 \\
\hline
\end{tabular}

\section{Source: Output of Research Data Analysis Results, 2021}

By looking at table 4, it is known that all of the variables Cronbach's Alpha and Composite Reliability values are above 0.70 so that all variables are declared reliable.

\section{Inner Model}

The structural model (inner model) is described as a model between constructs (latent variables) that are interconnected. The relationship between these constructs 
(latent variables) is based on certain theories or assumptions (Azuar Juliandi, 2018)

\section{R-Square}

R-Square is used for the dependent construct in the evaluation of the structural model. Using the R-Square value to assess the effect of certain endogenous variables and whether exogenous variables have a substantive effect (Ghozali \& Latan, 2015). The results of the R-Square value of 0.75 identify the strong model, 0.50 identify the moderate model, and 0.25 identify the weak model (Ghozali \& Latan, 2015).

Table 5

R-Square Value

\begin{tabular}{cc}
\hline Variable & $\boldsymbol{R}$-Square \\
\hline Employee Performance & 0.658 \\
& \\
\hline
\end{tabular}

\section{Source: Output of Research Data Analysis Results, 2021}

Based on the R-square value in table 5, which is 0.658 , it means that $65.8 \%$ of the variation in this case changes in employee performance is influenced by the outsourcing system and the remaining $34.2 \%$ motivation is influenced by other variables that were not studied. So that the S-Square value on the employee performance variable can be categorized as moderate.

\section{Direct Effect Hypothesis Test}

Testing the direct influence hypothesis was carried out to determine the structural relationship between latent variables on the path coefficient between variables by comparing the p-value with alpha $(0.005)$ or t-statistics of $(>1.96)$. The magnitude of the P-value and also the t-statistics can be seen in table 6.

Table 6

Path Coefficient Value

\begin{tabular}{|l|c|c|}
\hline \multicolumn{1}{|c|}{$\mathbf{X} \rightarrow \mathbf{Y}$} & T Statistik & P Values \\
\hline Motivation (X1) $\rightarrow$ Employee Performance $(\mathrm{Y})$ & 0.803 & 0.423 \\
\hline $\begin{array}{l}\text { Outsourcing System }(\mathrm{X} 2) \rightarrow \text { Employee } \\
\text { Performance }(\mathrm{Y})\end{array}$ & 5.265 & 0.000 \\
\hline
\end{tabular}

Source: Output of Research Data Analysis Results, 2021

\section{Hypothesis test results 1}

Based on table 6 , the P-Value value is $0.000<0.05$ or with a $\mathrm{T}$ statistic of 5.265 $>1.96$ then $\mathrm{H} 1$ is accepted. This means that the outsourcing system has a positive and significant effect on employee performance.

\section{Hypothesis test results 2}


Based on table 6 , the P-Value value is $0.423>0.05$ or with a T statistic of 0.803 $<1.96$, then $\mathrm{H} 2$ is rejected. This means that motivation does not have a positive and significant effect on employee performance.

\section{Discussion}

Based on the results of the direct influence hypothesis research, it is known that the outsourcing system has a positive and significant effect on employee performance. That is, the better the implementation of the provisions of the outsourcing system, the more employee performance will be. In labor law, outsourcing can be found implicitly in Law no. 13 of 2003 concerning Manpower. This is in line with the results of research from (Maryam Dunggio \& Rosario, 2020) which states that the outsourcing system has a positive effect on employee performance.

From the results of the direct influence hypothesis research, it is known that motivation has no significant effect on employee performance. The cause of the results of the study of motivational variables does not affect the possibility because in the company there is no reward, training and career development program, so motivation does not really affect employee performance. The results of this study are not in line with research from (Mardiyah Tusholihah, et.al., 2019) which states the results are that motivational variables have a significant influence on employee performance at PT. CITUS. Then it is not in line with research (Ketut IR Sudiardhita, 2018), which states that work motivation has a positive and significant effect on employee performance.

\section{CONCLUSION}

Based on the results and discussion above, it can be concluded that all the data presented have met the requirements of each parameter indicating that it is valid and reliable. The results of the hypothesis in this study that the outsourcing system has a positive and significant effect on employee performance. The results of the hypothesis that the motivation variable has no significant effect on employee performance.

\section{Recommendation}

Suggestions for management in order to increase work motivation for employees by holding training programs, providing rewards for employees who excel, and working with users in developing employee careers to create high motivation in employees which in turn can improve employee and company performance.

\section{REFERENCES}

Anak Agung Prabhaputra, I Nyoman Putu Budiartha dan I Putu Gde Seputra. 2019. Sistem Outsourcing Dalam Hubungan Industrial Di Indonesia (Outsourcing System In Industrial Relation In Indonesia). Jurnal Analogi Hukum Vol. 1 No 1.

Azuar Juliandi. 2018. Modul Pelatihan Structural Equation Modeling-Partial Least Square (SEM-PLS) dengan Smart PLS. DOI: 10.5281/zenodo.1243777

Dr. Emron Edison, Dr. Yohny Anwar, Dr. Imas Komariyah. 2020. Manajemen Sumber Daya Manusia. Penerbit Alfabeta. Cetakan kedua.ISBN: 978-602-289-216-8. 
Dr. Fazil Senol. 2014. The Effect Of Job Security On Perception Of The Internal Motivation Means : A Research From Turkey. Manas Social Studies Vol:3 No: 1

Ketut IR Sudiardhita, Saparuddin Mukhtar, Budi Hartono, Herlitah, Tuty Sariwulan, Sri Indah Nikensari. 2018. The Effect Of Compensation, Motivation Of Employee and Work Satisfaction To Employee Performance PT. Bank XYZ (PERSERO). Academy of Strategic Management Journal. Volume 17, Issue 4.

Mardiyah Tusholihah, Ardi Nupi Hasyim, Astry Novitasari, Puja Pauziah Oktavia, Fanny Indah Lestari, Muhamad Fadl, Ahmad Miftah Sobari. 2019. Pengaruh Motivasi dan Disiplin Kerja Terhadap Kinerja Karyawan Outsourcing. E-Journal Equilibrium Manajemen. Volume 5 Nomor 2 .

Maryam Dunggio, Rosario. 2020. Pengaruh Sistem Outsourcing dan Kompensasi Terhadap Kinerja Karyawan Pada PT. Astra International TBK Auto 2000. Mediastima volume 26 No 2. E-ISSN 2746-6493. P-ISSN 0852-7105

Michael Howe and Russell E. Johnson. 2016. Work Motivation. The Encyclopedia of Adulthood and Aging, First Edition. Edited by Susan Krauss Whitbourne. John Wiley \& Sons, Inc. by John Wiley \& Sons, Inc. DOI: 10.1002/9781118528921.wbeaa122

Muhammad Tafrizi Priarso, Prastiyo Diatmono, Siti Mariam. 2018. The Effect Of Transformational Leadership Style, Work Motovation, And Work Environment On Employee Performance That In Mediation By Job Satisfaction Variables In PT. Gynura Consulindo. Business and Entrepreneurial Review E-ISSN 22524614 Vol 18 No 2

Prof. Dr. Sugiyono. 2019. Metode Penelitian Kuantitatif, Kualitatif dan R\&D. Penerbit Alfabeta Cetakan Ke 27. ISBN: 979-8433-64-0.

Prof. Drs. H. Imam Ghozali M.Com, Ph.D, Ak \& Hengki Latan, SE. 2015. Partial Least Squares Konsep, Teknik Dan Aplikasi Menggunakan Program SmartPLS 3.0. (Untuk Penelitian Empiris) Edisi 2. Badan Penerbit - Undip. ISBN : 979.704.300.2

Rachmawati Rachman. 2019. Pengaruh Manajemen Outsourcing Terhadap Kesejahteraan Sumber Daya Manusia Di PT. GSD. Jurnal Manajemen Jaya Negara. ISSN: 2548-9348. Vol 11.

Rahmad Solling Hamid,SE,MM\&Dr. Suhardi M Anwar,Drs,MM. 2019. Structural Equation Modeling (SEM) Berbasis Varian : Konsep Dasar dan Aplikasi dengan Program SmartPLS 3.2.8 dalam Riset Bisnis. PT. Inkubator Penulis Indonesia (Institute Penulis Indonesia). 